\title{
Civilisations
}

Revue internationale d'anthropologie et de sciences

humaines

$54 \mid 2006$

Expériences de recherche en République

démocratique du Congo

\section{The Interface between Tradition and Modernity}

The Struggle for Political Space at the Local Level in Malawi

\section{Blessings Chinsinga}

\section{(2) OpenEdition}

Journals

Electronic version

URL: http://journals.openedition.org/civilisations/498

DOI: $10.4000 /$ civilisations.498

ISSN: 2032-0442

\section{Publisher}

Institut de sociologie de l'Université Libre de Bruxelles

\section{Printed version}

Date of publication: 1 April 2006

Number of pages: 255-274

ISBN: 2-87263-006-6

ISSN: 0009-8140

Electronic reference

Blessings Chinsinga, "The Interface between Tradition and Modernity », Civilisations [Online],

54 | 2006, Online since 01 April 2009, connection on 19 April 2019. URL : http://

journals.openedition.org/civilisations/498; DOI : 10.4000/civilisations.498 


\title{
VARIA
}

\section{The Interface between Tradition and Modernity \\ The Struggle for Political Space at the Local Level in Malawi}

\author{
Blessings CHINSINGA
}

Summary: This article seeks to demonstrate how traditional leaders have strategically exploited the decentralization policy reforms to reassert themselves as a dominant force in grassroots politics in Malawi. This assessment is situated within the context of the debate about the relevance of traditional leadership institutions or alternatively culture in the twin processes of democratisation and decentralisation. While one side of the debate dismisses them as sheer obstacles, the other side argues that they are a resource that can be tapped into in order to effectively domesticate the reforms, since traditional leaders embody values and virtues of political accountability, transparency and probity. The underlying argument of this article is that while research findings demonstrate that traditional leaders have indeed the potential to play a midwife role in the efforts to domesticate and customize the reforms to the exigencies of local conditions, their ill material circumstances render them overwhelmingly easy targets for politicians bent on satisfying their own strategic political considerations.

Keywords: decentralization, democratization, tradition, traditional leaders, councilors, political space.

Résumé : Cet article analyse la manière dont les autorités traditionnelles ont instrumentalisé les réformes liées à la décentralisation au Malawi pour se repositionner comme force dominante sur la scène politique locale, en milieu rural. Cette affirmation s'inscrit dans le débat plus général portant sur la pertinence des institutions politiques traditionnelles et de la culture dans le double processus de démocratisation et de décentralisation. Certains auteurs appréhendent ces éléments comme un obstacle, d'autres, comme une ressource susceptible d' "endogéniser " les réformes puisque les chefs locaux incarneraient les valeurs de responsabilité, de transparence et de probité. Si les résultats de l'enquête montrent que les autorités traditionnelles peuvent bel et bien constituer un élément facilitateur pour intégrer les réformes dans le cadre local, leur condition économique précaire fait d'eux des cibles faciles pour des politiciens qui cherchent à satisfaire leur propre agenda politique.

Mots-clés : décentralisation, démocratisation, tradition, chefferie traditionnelle, espace politique. 


\section{Setting the Context}

The implementation of decentralization policy reforms - billed as the centrepiece of major policy reforms underway in developing countries - has either opened up or substantially widened political space for manouvre for the gallery of actors engaged in the process within the fabric of local politics often resulting in quite intense struggle over this space. These actors, which among others, include elected bodies (councilors), customary authorities (chiefs or traditional leaders), administrative appointees, local representatives of technical services and ministries, community groups, development committees, and non governmental organizations (NGOs) basically jostle and wrestle for power, influence and authority in an attempt to entrench and legitimate themselves as dominant forces in grassroots politics in the burgeoning new social, political and economic order (Gould 2001, Obario 2002, Raftopolous 2002). While a wide range of actors are embroiled in the contests over this emerging political space at the local level, the intensity of this struggle has been strikingly pronounced between elected representatives (councilors) and customary authorities (chiefs) in most countries implementing decentralization policy reforms of one form or another. Consequently this struggle is predominantly framed in terms of tradition versus modernity since customary authorities and elected representatives are widely postulated as embodiments of tradition and modernity respectively.

This development is however taking place against the backdrop of a troubled if not a checkered history for customary authorities. In the greater part of postcolonial Africa, traditional leaders were either banned or their powers substantially circumscribed ${ }^{1}$. For example, the slogan in Mozambique against customary authorities was "kill the tribe and build the nation" (Gould 2001: 8). The general pattern of distaste of the customary authorities in the postcolonial era is largely attributed to the intermediary and facilitatory roles chiefs played during the processes of colonization. Through indirect rule schemes, chiefs had their legitimacy heavily eroded and tainted "[by] the excesses and contradictions that external backing and exigencies of colonial administration produced" (Ribot 2002: 67). It however appears that the current waves of democratization and decentralization sweeping across the continent are rapidly giving chieftaincy a new lease of life. Traditional leaders have apparently reasserted their authority in Burkina Faso, Chad, Ghana, Ivory Coast, Mozambique, Nigeria, Senegal, South Africa, Tanzania, Zambia and Zimbabwe (Ntsebeza 1999, Raftopolous 2002, Blom 2002). Paradoxically the reemergence of traditional leaders is in fact in some countries being further propped up by central political authorities. The South African and Malawian constitutions for instance recognize chiefs as legitimate actors in the local governance processes. The South African constitution in fact explicitly recognizes the right and the existence of traditional

1. Note that this article draws heavily from the experiences of Anglophone Africa. Examples of countries in which traditional leaders were abolished include Tanzania, Uganda and Zimbabwe. In Kenya, Malawi and Zambia, their powers were substantially neutralized and circumscribed. For some details see for example O’Laughlin 2000, Gould 2001, Raftopolous 2002, Senyonjo 2004. 
communities to self govern under various systems of indigenous law. In a similar spirit, the 1992 Mozambique peace accord stipulates that "the government undertakes to respect and not antagonize the traditional structures and authorities where they are currently de facto exercising authority" (Ribot 2002: 21). Stunningly the reemergence of traditional leaders is increasingly being held as "the panacea for the achievement of decentralized, pluralistic democratic cultures and the strengthening of civil society" (Obario 2002: 4) and are further idealized as "a romantic category of legitimate popular local leader" (Ribot 2002: 52).

While the critical thrust of the findings of the study on which this paper is based demonstrates that traditional leaders have the potential to play a midwife role in the efforts to domesticate and customize the reforms to the exigencies of local conditions, the underlying argument of this article is that their ill material circumstances render them overwhelmingly easy targets for politicians bent on satisfying their own strategic political considerations thereby entrenching the upward rather than the downward pattern of accountability which is the hallmark of the twin processes of democratization and decentralization. Understanding the implications of decentralization policy reforms therefore requires a detailed understanding of the actors being created, supported and empowered in the resulting political landscape and their relationship to both the central state and the local population. The main challenge though is that the legal and technical logics of reform processes do not neatly fit in the diverse logics of local politics which almost always takes on a rhythm of its own.

\section{Who are Chiefs? Traditional Leaders in Malawi}

Two questions are quite pertinent here. Who are chiefs and where does their authority and legitimacy come from? These are extremely difficult questions to address mainly because of the variegated experiences the institution of chieftaincy has been subjected to in the last hundred years or so across the African continent. Both colonial and postcolonial regimes have in different ways, and for various strategic considerations, mutated the shape and form of customary authorities. The tendency for colonial authorities was to replace non-compliant and rebellious chiefs with handpicked loyalists regardless of their status in their respective communities in a bid to facilitate the processes of subjection and domination. In the postcolonial regimes, changes have included either the introduction of appointment or election systems for chiefs. Chiefs are appointed by the government or elected on a competitive basis by members of a community ${ }^{2}$. In extreme cases, the chieftaincy has either been suspended or abolished altogether. These changes are however in stark contrast with the nature of chieftaincy as practiced in the pre-colonial era where it traces its roots. Chiefs almost exclusively derived their authority and legitimacy either as descendants of a great ruling ancestor or on the basis of membership in a particular ruling family (Karlstrom 1996, O’Laughlin 2000, Ribot 2002). But the alterations regarding the basis of claims to chieftaincy masterminded by colonial and postcolonial regimes notwithstanding, the right to chieftaincy on the basis of descent has persisted, and by and

2. Chiefs in Uganda are elected since 1986 when Museveni came to power and constituted the Resistance Movement (RC) system. In Kenya, chiefs are appointed by the government since independence in 1963. The appointees must satisfy specially set criteria including at least four years of secondary school education. This has led some people to argue that chiefs are merely administrative auxiliaries of the state. 
large, remains the dominant means of ascending to chieftaincy in most areas where the institution has survived. This is the exclusive means for individuals to legitimately ascend to traditional leadership positions in Malawi (Moto 1998).

It is against this backdrop that chieftaincy is predominantly defined in terms of tradition. According to Senyonjo (2004), tradition is any cultural product that was created or pursued in whole or in part, by past generations and that having been accepted and preserved, in whole or in part, by successive generations has been maintained to the present. Lule (1995) defines tradition as something done or respected according to custom from generation to generation. Tradition among other things entails outlooks on life, values, practices and ways of relating or resolving disputes including various institutions inherited from previous generations. For this reason, Owusu (1997) and Senjonyo (2004) argue that every society in this world is traditional in as much as it maintains and cherishes values, practices, outlooks and institutions bequeathed to it by previous generations.

Traditional leaders are at the heart of custom and culture in the sense that they play a prominent role in efforts to preserve them. They are variously described as "guardians of traditional norms, values and practices that are respected in particular communities from generation to generation - and as such [they] are an important channel through which social and cultural change can be realized" (Senjonyo 2004: 2); "actors and embodiment of customary decision making institutions" (Blom 2002: 109); and "a socio-political expression of local African social organizations which is based on lineage and quite key to the continuity of societies" (Soiri 2002: 8). As a social-political expression of local African social organizations, chieftaincy entails power and influence which incumbents wield over a distinct territorial unit occupied by a largely homogenous people sharing more or less a common culture, social values and aspirations. This means that a traditional leader cannot exist without a distinct territory and a socio-political organization over which he exercises governance, power, authority and influence. The village is the most common unit of social aggregation where traditional leaders operate. Typical villages usually have about 100 to 2000 people organizing various aspects of their livelihoods such as agriculture, woodlands and fisheries under the leadership of a village chief. These chiefs have the status of an administrative magistrate presiding over customary, civil and even commercial disputes. Often their judgments are much more respected and so tend to bring about lasting peace and reconciliation among family members, clan members and even between clans (Lule 1995).

There are six recognizable levels of chieftaincy in Malawi defined primarily in terms of the size of the territory over which they have jurisdiction. At the summit of the hierarchy are Paramount Chiefs followed by Senior Chiefs; Chiefs; Sub-Chiefs; Group Village Headmen; and Village Headmen. As of February 2004, according to the statistics maintained at the chief's administration unit at the Department of Local Government, there were three Paramount Chiefs; 24 Senior Chiefs; 121 Chiefs; 61 Sub-Chiefs; 2360 Group Village Headmen; and 18361 Village Headmen.

Chiefs have apparently been consistently at the centre of the efforts to propagate local governance structures in Malawi. In the initial phases of colonial rule, chiefs were incorporated into the administrative system as assistants to District Commissioners as early as 1912. Some of the chiefs served as such upon being elected by the colonial government regardless of whether they belonged or not to the ruling clans in their respective communities. Following the promulgation of indirect rule in 1933, chiefs were conferred legislative, judicial and fiscal powers over their respective jurisdictions. These 
powers were however revoked in 1953 following the launch of statutory district councils (Baker 1995, Kaunda 1992).

The 1967 Chiefs' Act propagated after independence in 1964 spelt out their role as "aides to the central government particularly in the field of security, law and order" (Baker 1995: 59). They thus became deeply enmeshed into the one party administrative apparatus as handmaidens of the District Commissioner in his task of peace, law and order enforcement. They had to cooperate with the party, the District Commissioners, and security forces to ensure peace and calm. Chiefs who engendered any semblance of trouble and disloyalty were swiftly dethroned. However despite these fundamental political, economic and social changes, traditional leadership institutions have demonstrated unprecedented resilience, and as demonstrated below, continue to influence political processes and determine opportunities and constraints for democratic development within the framework of the decentralization policy reforms.

\section{Traditional Leadership, Democracy and Decentralization}

Whether or not traditional leadership is compatible or incompatible with democracy and decentralization is intensely debated. In this debate two schools of thought can be broadly distinguished. The first school of thought perceives traditional institutions as being incompatible with democratization and decentralization whilst the second school of thought argues for co-existence of some kind since traditional leadership institutions are an important part of the historical heritage of local communities and cannot therefore just be wished out of existence (Ray 1996, Blom 2002, Ntsebeza 2003).

The critics of traditional leadership institutions argue that traditional authority is an anachronism that should not have survived the twentieth century let alone exist in the twenty first. Traditional leaders are thus characterized as leftovers from a time that is swiftly fading away. The thrust of the discourse against traditional leadership institutions hinges on Mamdani's thesis of the bifurcated state. The colonial state according to Mamdani (1996) was bifurcated because it had different modes of rule for urban citizens and rural subjects. In his view therefore nothing less than dismantling the bifurcated state would ensure complete democratization of developing countries, and consequently, facilitate the potential success of decentralization policy reforms since only then can both rural and urban areas enjoy a common citizenship. This would be impossible to achieve if traditional leadership institutions remain intact since this would mean the continuity of a "series of binary opposites such as rights and custom, representation and participation, centralization and decentralization, civil society and community" (Ntsebeza 2003: 56). Traditional institutions are thus seen as instruments of social oppression entirely devoid of progress especially in such areas as political organization, women's rights, social mobility and economic rights.

Customary institutions are further criticized as being undemocratic principally on the grounds that the right to choose one's representatives is a fundamental and basic human right in contemporary democracies. This is the case because chieftaincy is more or less "a caste in which only birth members can postulate to the role of chiefs" (Ribot 2002: 69). A traditional leader in South Africa captures these sentiments even more crisply. He points out that "Traditional leaders such as myself rise to power through birthright; my father was a king, and I am his heir. Elected officials on the other hand get their authority by means of a popular vote" (Molotlegi 2002: 1). The issue here therefore is that as long as chieftaincy 
is based on heredity and ascription then it is inherently undemocratic. The possibility of rural residents having the freedom to choose which institutions or individuals should rule is automatically excluded. The major concern is that ascendancy to chieftaincy on the basis of ascription makes incumbents hardly accountable to their subjects, and as such, empowering or working with them may not serve the efficiency, equity or development aims so often strongly idealized by somewhat naïve decentralization advocates (Ribot 2002, Ntsebeza 2003). The argument is that working with or empowering chiefs may simply amount to the continued encapsulation of individuals within communities through the administratively driven empowerment of customary decision makers to represent local people (Mamdani 1996). The hallmark of this school of thought therefore is that traditional and modern forms of leadership cannot co-exist because they draw their legitimacy from two distinct sources. Traditional leaders derive their claims to legitimacy, authority and, indeed, sovereignty from their pre-colonial roots while the contemporary African state is a creation of, and a successor to, the imposed colonial state.

On the contrary, the supporters of traditional leadership institutions contend that these institutions can neither be simply legislated out of existence nor merely be relegated to being part of a traditional social sphere distinct from the modern world of civil society (Owusu 1997, Blom 2002, Senyonjo 2004). The major thrust of the argument of this school of thought is that traditional leadership institutions are not static and frozen in time. Like all aspects of culture and tradition, it is argued that the institution of traditional leaders grows and adapts itself to the changing values and aspirations of its people since it does not exist in a vacuum. It is the ordinary people who condition it and reshape it to be constantly relevant. The values of democracy, participation, respect for human rights, mutuality and cooperation with others all influence the nature and functioning of the institution of traditional leaders in the contemporary society.

In order to appreciate the relevance of chieftainship, Owusu (1997) and Blom (2002) for instance argue that it is extremely vital to understand how it is based on customary village institutions involving general norms and ideas about leadership. They contend that a ruler's subjects are fully aware of the duties he owes to them as they are of the duties they owe to him and are able to exert pressure to make him discharge these duties. In some cases, according to Moto (1998), a chief may in fact, by popular will, be stripped of his chieftaincy if his behaviour is not that expected of a chief and associated with the office. In this sense the power of chieftaincy largely rests with the chief's subjects and should a chief not live and lead as expected, the subjects have the mandate to ask for their removal. Chieftaincy is therefore widely perceived as an embodiment of virtues of political accountability, transparency, service and probity. It is further argued that traditional leaders play a very critical role in the livelihoods of their subjects in the sense that: 1) they inspire and motivate their people for development in every aspect; 2) advocate cooperative action; and 3) extols the commitment and total involvement of all members of a community in forming and implementing policies for overall community welfare. They are able to achieve these goals because "their word is much respected, their praise is much appreciated, and their example is emulated" (Lule 1995: 18). Lule (1995) in fact argues that the institution of traditional leaders being part and parcel of the cultural heritage of African people is an essential part of their fundamental right to culture. Once the people who are affected by it freely choose to have it, it can therefore not be legislated out of existence simply because it is incompatible with democratization and decentralization. 
This school of thought takes recourse to the apparent resilience of customary authorities to argue for a critical role that traditional norms, values and practices may play in domesticating the twin processes of democratization and decentralization. The fact that the suppression or even the abolition of traditional institutions and leadership could not wipe their importance in the eyes of the grassroots, it is argued, should be taken as a starting point for any attempt to mediate the interface between tradition, democratization and decentralization. From this vantage point, domesticating democracy thus entails "a dynamic and continuous process of institutionalization in which democratic ideals, beliefs, values, practices, actions and relationships, and new forms of political behaviour gain acceptance and popular support in society and become successfully integrated with other features of culture and society endowing them with popular legitimacy" (Owusu 1997: 121).

Supporters of this school of thought therefore argue that traditional institutions provide an adaptation mechanism of new ideas through reference and contrast to preexisting ones. In this sense traditional institutions thus form the foundation on which new concepts are built and this foundation "enables the people to incorporate new ideas into their body politic without losing the essential elements of their own tradition and also makes the new concepts understandable" (Senyonjo 2004: 5). Consequently it is argued that any hope for sustainable democratization and decentralization very much depends on "courage, honesty and imagination with which [the interface between tradition, democratization and decentralization] is addressed" (Owusu 1997: 132). The key issue here is that "the western models of governance should be complemented with political forms rooted in African imageries" (Obario 2002: 5) since "to disregard or trample on traditional institutions is to antagonize the people and perhaps even earn their opposition" (Senyonjo 2004: 5) and perhaps even "more critically tradition gives us our identity, our values, and a way of discriminating between change as progress and change for the sake of change" (Molotlegi 2002: 11).

\section{Empirical Setting}

\section{The Struggle for Political Space between Chiefs and Councilors}

This paper is based on a study carried out to examine the politics of poverty reduction in the context of political and administrative reforms in Malawi focusing chiefly on the patterns of power structures and relationships among institutional actors and stakeholders at various levels of government and society. This study was motivated by the widespread conviction specially hyped by donors that the advent of democracy in a polity coupled with democratic decentralization creates or widens political space for engagement between the state and society (Webster and Engberg-Perdersen 2002, Hickey 2003). This in turn curves out favourable patterns of interaction among various actors and stakeholders for viable governance and poverty reduction efforts since it, inter alia, involves building the political capabilities of the poor to exercise their political voice through which they can demand improved services.

However, for the purposes of this paper, the notion of political space is defined as the possible range of arenas of contestation by a variety of actors at various levels of society usually over mutually valuable resources and interests. Political space thus offers protagonists the opportunity to contest, challenge and influence the ways in which decisions about their mutual interests and concerns are formulated, executed and even controlled. 
The struggle over political space according to Lefebvre (1991) thus entails an interplay between social and power relations shaped by locally situated knowledge and practices in which the contestants often take recourse to planes of discourse, influence, legitimacy and authority in which they have visibly and symbolically significant comparative advantage. This therefore implies that there are multiple political space(s) in which the very same actors might interact but in which they may invoke widely different registers of discourse, influence, legitimacy and authority befitting the context or encounter at a particular point in time. The critical point here is that who creates, occupies and controls the entry to different types of spaces determines whose voice is heard and who accesses resources and decisions. Political space can therefore either continue to reproduce the statusquo of power relations or it can fundamentally challenge and rewrite the rules of the political game altogether.

Using semi-structured interviews and focus group discussions, the study was carried out in six districts across the country ${ }^{3}$. A pair of districts was chosen in each administrative region, one of which was a Local Impact Area (LIA). LIAs are those districts in which the decentralization policy reforms were piloted under the auspices of the district focus policy initiative launched in 1993 before they were officially replicated to the rest of the country in $1997^{4}$. The purposeful inclusion of the LIAs was meant to provide benchmarks for comparative analysis of the findings especially given that they have a relatively longer history in the implementation of the decentralization policy reforms in their respective development planning, administrative and management regimes. The reforms culminated in the formation of District Assemblies (DAs) as the focal point for governance and development in districts which were formally constituted following local elections held in November 2000. Strikingly the findings of this study did not show any distinct differences between LIAs and non-LIAs.

The gist of the findings of this study is that the problematic relationship between customary authorities and councilors arises principally because the former want to constitute primary structures of local government in rural areas. They are strongly opposed to the introduction of alternative structures of leadership that appear to challenge the hegemony of their power, prestige, influence and authority. In the resultant struggle, the results of this study indeed underlies the multifaceted nature of political space especially in terms of the strategies used by the councilors and traditional leaders to gain influence,

3. Note that Malawi is divided into three administrative regions, namely, north, centre and south. These regions are in turn divided into districts. Until 1994 Malawi had 24 districts: five in the north; nine in the centre; and ten in the south. It has now 29 districts: six in the north; nine in the centre; and fourty in the south. The additional five districts have been created between 1994 and 2004 following presidential directives justified as a means for facilitating rapid socio-economic development processes.

4. UNDP extends development assistance to Malawi in five-year cycles. Each cycle focuses on specific development issues. The 5th development assistance cycle, spanning between 1992-1997, specifically targeted institutional and policy reforms of Malawi's development administrative and management regime in the wake of rapidly deteriorating living standards. Special focus was on the District Development Committee (DDC). This led to the launch of institutional and policy reforms on a pilot basis in six districts spread across the country designated as Local Impact Areas (LIAs) before being replicated to the rest of the districts in 1997. These included Nsanje, Thyolo and Mangochi in the south; Dedza and Mchinji in the centre; and Nkhata Bay in the north. LIAs sampled for the study included Thyolo in the south; Mchinji in the centre; and Nkhata Bay in the north. Non-LIAs included Mwanza in the south; Ntchisi in the centre; and Rumphi in the north. 
authority and legitimacy in the various arenas in which the contests are waged. They thus, as illustrated below, use different registers or discourses to justify their levels of influence, authority and legitimacy. Councilors often take recourse to democracy as the primary basis for their influence, authority and legitimacy whilst traditional leaders trace their influence, authority and legitimacy to cultural heritage (tradition and custom) particularly the ownership of land that is vested in them. The other dimensions of the struggle borders on age (young versus old) and education (educated versus uneducated). Councilors are perceived as young and uncultured by traditional leaders such that they are deemed to lack the depth of experience, wisdom and skills to make sound judgments and decisions. On the contrary councilors perceive traditional leaders as uneducated and therefore old fashioned and more or less irrelevant to the modern day needs of society. They thus argue that their cultural competence, experience and wisdom are pretty much obsolete. The sentiments of Chief Chikulamayembe of Rumphi DA are quite illuminating on the dynamics of these rival registers employed in the struggle for influence, authority and influence. He pointed out:

\begin{abstract}
While the traditional system reveres the wisdom and experience of the elders in the community and confers on them great responsibility for making decisions on behalf of their respective communities, the overzealous faith in democracy not only puts elders and youth on an equal footing but it dismisses the knowledge and insights of those who may not be as educated as their children. But with the quality of education of these days - where even a high school leaver cannot convincingly read and write - this dogma is ill founded.
\end{abstract}

This struggle between councilors and traditional leaders however needs to be properly contextualized in order to begin to grasp it. The position of councilor is not entirely new on the country's political landscape but it had been dormant between 1992 and 2000. This was necessitated by the country's transition to democracy. All sitting councilors at that time had to relinquish their posts because they all, by definition, belonged to the then ruling Malawi Congress Party (MCP). After all, until the early 1990s when the multiparty system of government was introduced, every Malawian was a member of the MCP by virtue of birth. The expectation was that councilors would be re-elected immediately after the May 1994 general elections.

This did not however happen until November 2000. This meant that traditional leaders had more or less become de facto the most influential actors in village or local level politics. In fact, in the view of most traditional leaders interviewed, "the position of councilor had more or less effectively disappeared from the local level political landscape"s. It is therefore not surprising that the reconstitution of the position of councilor following the November 2000 local elections has been consistently interpreted by traditional leaders as "an unnecessary intrusion into village politics that has thrown virtually stable local power hierarchies into a state of disequilibria"6. The resultant situation has been described as "putting two bulls in the same kraal"7. Two major sources of conflict between traditional leaders and councilors can broadly speaking be distinguished. According to the findings of this study, the conflictual relationship between councilors and traditional leaders

5. Interview with Chief Zulu in Mchinji DA.

6. Interview with Chief Bvumbwe in Thylo DA.

7. Interview with Chief Nkumbira in Nkhata Bay DA. 
borders on what could be characterized as the imperatives of tradition and the legislative framework guiding the activities of DAs.

\section{Imperatives of Tradition}

Tradition vests ownership of villages or broadly said land in customary authorities. By implication therefore "all people whether councilors, MPs or even the President are subjects of traditional leaders in which case we have to be primary institutions of leadership at local level otherwise nothing can happen on our land"8. The position of most traditional leaders therefore is that they cannot operate under the guidance of councilors who are their own subjects and "most of them are young boys who still have to go to school". Their relationship is further worsened by the fact that "some councilors view themselves as being at the same level or even higher than traditional leaders"10. The main reason why councilors view themselves as superior is that "their areas of jurisdiction are bigger than those for Village Headmen and Group Village Headmen"11. Some chiefs further argued that councilors consider themselves superior "because they are elected and hence think they are rightful leaders"12. This was nevertheless challenged as the basis for councilors' legitimacy by some chiefs arguing that "if one looks at the number of people that elected them, then, their legitimacy is pretty questionable"13. Their argument is based on the fact that very few people voted during the November 2000 local government elections with an estimated voter turnout of only $14 \%$. As such traditional leaders often evoke the posterity of their positions contending "the role of councilors is undermining their position as proven custodians of culture, tradition and development"14.

This tension often comes to the fore in public ceremonies involving traditional chiefs and councilors. Funerals in Malawi are, due to the devastating HIV/AIDS pandemic, a regular occurrence. In the course of the fieldwork for this study, I encountered and observed several funeral ceremonies and rituals for when there are such activities in a community other facets of life come more or less to a virtual standstill. These ceremonies are usually characterised by a distinct protocol of speeches. Usually the people lined up to speak include maternal and paternal representatives of the families of the deceased, the village head, party representatives (often councilors) and employers' representatives (if the deceased was in formal employment). Church officials take over after these speeches, that is, if the deceased belonged to any religious denomination. In one of the funeral ceremonies that I attended in Mchinji DA, the struggle between traditional leaders and councilors broke out in the course of the ceremony. After the maternal and paternal representatives of the deceased had spoken, it was the turn of the councilor to speak and then the village head after which the church officials would take over the ceremony.

\footnotetext{
8. Interview with Chief Chikulamayembe in Rumphi DA.

9. Remarks by a Village Headman in a Men's FGD from Kamtsonyo Village in Thyolo DA.

10. Interview with Chief Chikulamayembe in Rumphi DA.

11. Interview with Village Headman Malengamzizi in Ntchisi DA.

12. Interview with Chief Nkumbira in Nkhata Bay DA.

13. Interview with Chief Zulu in Mchinji DA.

14. Interview with a councilor in Ntchisi DA.
} 
As the councilor stood up and cleared up his throat to speak, a large proportion of the crowd could be heard murmuring in fairy audible voices. Part of the crowd were wondering at the fact that they had a councilor while others were grumbling about the appearance of councilors only on formal occasions such as funerals arguing that the councilors cannot miss such occasions because of the special recognition and treatment that they are accorded mainly in terms of food. In his speech, the councilor briefly consoled the bereaved family, and almost to the surprise of everybody, veered into politics marketing himself to the audience. He pointed out that it was quite important for the people to realize that they now have councilors who are going to be very instrumental in developmental activities in this new era of democracy. He went on to say that villages that would not link up with him are going to be marginalized in the development process since he is now "the legitimate voice of the people".

The village head did not even wait to be called upon by the masters of ceremony to speak. He spontaneously sprang up to his feet immediately after the councilor concluded his speech. Almost instinctively, he began his speech by expressing dismay and shock at the conduct of the councilor, and barely managed to restrain himself from streams of outbursts directed at the councilor before first consoling the bereaved family as protocol would demand. "The conduct of our councilor is quite provocative but before I can comment more on it, let me first honour my task which has demanded our presence here". No sooner had he concluded consoling the bereaved family than he turned to the councilor. He pointed out that his behaviour was not only out of tune with cultural norms, values and practices but also underpinned an insatiable appetite and greed for power, influence and authority. He argued that there was need to separate politics from solemn occasions such as funerals. He observed that the councilor's conduct was culturally disrespectful not only of the dead but also of the bereaved families to use a funeral ceremony as a political platform. He went on to say: "This should be the first and last time for this kind of shameful act to happen. I have no doubt whatsoever in my mind that this borders on the fact that the majority our children today are not properly cultured such that they want to become elders when their time has not even beamed on the horizon. Leave development issues to us the owners of the land". The crowd once again audibly murmured but this time around choruses of approval of the chief's sentiments whilst the councilor simply buried his head in his hands pretty much motionless like a statue.

It is not surprising that customary authorities have used ownership of land vested in them by custom - as intimated above by the village head at the funeral ceremony - to frustrate the activities of councilors, especially if they are seen to be undermining their authority. The capacity of councilors to plan development projects is highly dependent on traditional leaders who control access to land in their respective localities. The standard practice is that "land cannot be procured without the approval of a traditional leader, and if any community projects are to be undertaken, it must be with his blessing"15. The councilor interviewed in Thyolo DA for example recalled to have mobilized his constituents for a borehole project. They formed a committee, identified a site and made all requisite preparations for the launch of the project. But when the contractor finally came, the village head directed him to drill the borehole in front of his house. The

15. Interview with a councilor in Rumphi DA. 
village head formed his own committee replacing the one that had been facilitated by the councilor. His argument was that he sees no need for councilors since he has been able to govern his subjects without them for a long period of time and "nobody has the right to make decisions over his land"16.

\section{The Legislative Framework for DAs}

Within the legislative framework of the DAs, the conflictual relationship between councilors and traditional leaders prevails because the latter feel the election of councilors has considerably diminished their authority. They in fact perceive councilors as "competitors because they are stripping them off of their once expansive domain of power, influence and authority"17. This is the case because traditional leaders are nonvoting members of DAs. The feeling among them is that this is a strategic ploy on the part of the councilors "to systematically downplay the importance of chiefs. Already some councilors argue that we no longer have chiefs by virtue of the fact that we do not vote in DAs" $"$.

DA meetings are quite rare because of the perennial problem of funding. Out of the six sites the study was carried out, it was only in Mwanza DA that I had the opportunity observe the DA in session. DA meetings bring together councilors, Members of Parliament (MPs), chiefs and the representatives of various interest groups even though at this particular meeting none of the parliamentarians in the DA was present. The DA bureaucrats participate in DA sessions but mainly to offer technical support and advice in the course of the deliberations. The official linguistic medium for transacting DA business is English. The interesting thing about this particular meeting was however the fact that the councilors exploited their knowledge of English even though somewhat rudimentary to marginalize the participation of chiefs in the deliberations. When chiefs sought clarifications on the issues being discussed councilors could either simply pass on documents written in English to the chiefs to read or argued that even if they or the bureaucrats could translate the issues into the local language, the chiefs would not understand them since they are complex issues requiring certain levels of knowledge and competence. Later on in my informal discussions with several councilors, they readily confessed that their conduct was deliberately orchestrated in order to show the chiefs that they are significant players in so far as development and policy issues are concerned.

The main motivation for this attitude they argued was the obstacles chiefs present in the course of their work contending that they have not been in a position to deliver because of the chiefs' retrogressive behaviour. One of the councilors pointed out that "[Chiefs] seem not to recognize let alone appreciate the fact we are the most legitimate leaders since we are elected by the people. We have the mandate of the people which they don't have. This is the hallmark of democracy. They have to realize that times have changed". Interestingly however, the DA bureaucrats use the same language instrument to short-circuit councilors on issues and procedures they want to tip in their favour. In this meeting, the bureaucrats frequently pitched the language to a higher level when they wanted the councilors not to fully grasp especially how the final resolutions of the

16. Interview with the Chairperson for Thyolo DA.

17. Interview with the Chairperson for Mwanza DA.

18. Interview with Chief Chikulamayembe in Rumphi DA. 
deliberations had actually been framed. The majority of the councilors are either holders of Junior Certificate or Malawi School Certificate of Education while the bureaucrats who take part in DA meetings are university graduates.

Chiefs consistently characterised the fact that they are non-voting members of DAs as quite unfortunate. They argued that they should have been voting members because "they are the ones who understand people's needs better, unlike councilors whose motive for development is political"19. Unlike them, they argued, councilors are partisan hence it is difficult for them to mobilize people from other political parties rather than their own to take part in development. The conflict between traditional leaders and councilors is even more pronounced where the leadership of the sub-district participatory structures has been taken over by popularly elected leadership ${ }^{20}$. They strongly feel the drive to introduce elected leadership in these structures has been instigated "by councilors who want to substantially undercut their power, authority and influence in grassroots politics" 21 . According to Chief Nkumbira in Nkhata Bay DA, they resisted the introduction of elected leadership in the sub-district participatory structures because "it would have further reduced our powers since we no longer preside over our own courts and we are nonvoting members of the DA".

\section{Self Seeking Politics in the Spotlight}

The study found out that the conflict between traditional leaders and councilors is in various ways fueled and fanned by widespread and entrenched self-seeking tendencies amongst politicians. Given the fragmented nature of the polity resulting from the May 1994 polls, politicians across the political divide have strategically turned to customary authorities in order to entrench and consolidate their legitimacy. In this regard, Awoh's (2004: 303) observations for Nigeria are equally true for Malawi since 1994:

In their [politicians] perpetual bid to hold on to power, they have found traditional rulers and their institutions as providing them with vital supplementary support for their weak bases of power. Even in the situations where government may claim legitimacy by way of general elections, there is ample evidence to show that traditional rulers have often been accomplices, for example, in election rigging, victimization, and use of traditional institutions to manipulate the electoral processes.

The findings of this study show that the government has particularly targeted chiefs as avenues for consolidating its legitimacy especially in the north and centre where its electoral strength has been considerably weak. It appears that politicians are fully aware that chiefs exert tremendous power, influence and authority over their subjects. The strategies used have included: 1) reinstating chiefs that were deposed during the one party era; 2) appointment of new chiefs; 3) promoting chiefs; 4) building houses and offices

19. Interview with Chief Nkumbira in Nkhata Bay DA.

20. DAs have a two tier participatory structures through which they are linked to the grassroots. Below DAs are Area Development Committees (ADCs) and then Village Development Committees (VDCs). Customary authorities have always chaired these structures until the constitution of DAs in 2000. However some chiefs strongly resisted giving up the leadership of these participatory structures resulting in hybrid leadership patterns. In some areas customary authorities chair the sub-district participatory structures whilst in others popularly elected leaders have taken over the chairmanship.

21. Interview with a councilor for Mwanza DA. 
for chiefs; 5) and putting all chiefs on the government's pay roll ${ }^{22}$. In stark contrast, councilors are not entitled to any of these privileges. They do not even have a salary. Their livelihoods are not dependent on being councilor but on a string of other jobs, and their predicament was aptly summed up as follows:

The institution of chieftaincy poses serious challenges to the question of representation. This is the case because traditional leaders are being recognized more than councilors. All chiefs are given accommodation and various material gifts. It is therefore inconceivable to expect councilors to prevail over chiefs. Even at political rallies, chiefs are given more recognition than councilors.

Since the fieldwork was conducted in the lead up to the June 2004 general elections, political rallies just like funerals were a frequent occurrence. In all the sites visited, I was able to witness and observe at least one political rally. The settings of these meetings are more or less identical. Nearly all of them take place in an open space, usually a football ground. The dignitaries sit on chairs, whose quality and comfort is differentiated on the basis of rank, in front of the crowds usually in a shade. The key speakers usually sit in the middle behind a table decorated with flowers and the rank of the dignitaries' decreases as one moves away from the centre in either direction. Women and youth usually sit a few metres away from the high tables. The women and youth in front often include groups of performers who entertain the crowds at various junctures of the political rallies. Men usually stand behind the women and youth unless they are amongst the contingent of performers.

The rallies, guided by a master of ceremonies, usually start with a prayer followed by an outline of speakers to address the meeting. This list usually includes the councilor, chief, Member of Parliament (MP), district governor, regional governor and the keynote speaker. This list however varies depending on the rank of the keynote speaker. Strikingly however, most of the rallies that I witnessed and observed, the master of ceremonies would often make the following caveat upon introducing the lineup of speakers: "Our councilor will be given the opportunity to speak depending on time since we have started our programme relatively late. Let us therefore straight away call upon the chief (gogo chalo or eni ntunda meaning "the owner of the land") to address us so that he conveys welcoming remarks to our guest of honour on behalf his people". Usually next to speak was the MP and only in one of the eight meetings that I observed was the councilor given the slot to speak after initially being sidelined on the pretext of a tight programme.

The rally that I witnessed and observed in Nkhata Bay DA was however quite exceptional. As is usually the practice, the councilor was sidelined in the list of the would be speakers at this rally. The chief was therefore the first one to speak. Surprisingly however when he stood to speak he insisted that the councilor should take to the podium before he can actually do so arguing that she plays a critical role in promoting the welfare of the people in the area under his jurisdiction. Keen to find out why the chief was strangely sympathetic to the councilor, I eventually found out that the chief and the councilor are

22. The salaries for chiefs have been recently adjusted upwards but backdated to January 2005 while councilors are not entitled to any perks. Paramount Chiefs get MK 5000; Senior Chiefs MK 4000; Chiefs MK 3000; Group Village Headmen and Village Headmen MK 1000 per month. See Government Raises Chiefs Perks, The Nation, 23rd March 2005. 
relations. The councilor is a niece to the chief. The fact that councilors are deprived of a voice in these political rallies, I discovered, is as a result of combined forces between the MPs and chiefs. The gist of the competition between chiefs and councilors has already been espoused above. MPs are jittery about councilors because they fear that given a platform, councilors might build a formidable political base with which to challenge their candidacy in the subsequent general elections. MPs are able to connive with, and lure chiefs because they have effectively emerged as prime patrons in the local level politics. Unlike councilors, they are entitled to a largesse of perks to the tune of more or less U\$ 1500 per month.

It was against this backdrop that some respondents even contended that some chiefs have gone to the extent of characterizing councilors as "slaves because of the lack of recognition by their own political masters, so why should we bother?"23. Since 1994 nine chiefs have been reinstated; 44 Group Village Headmen promoted to the position of Sub-Chief; 50 Sub-Chiefs promoted to Chief; and 24 Chiefs promoted to the position of Senior Chief. Before 1994, the position of Senior Chief did not exist in the chieftaincy hierarchy; it has therefore been purposefully created by the government in its relentless drive to extend its reservoir of legitimacy to all possible corners of the country. The root cause of the enduring vicious conflict between customary authorities and councilors is apparently the lack of clarity regarding the precise roles, functions and power of the various stakeholders in the decentralization process. This lack of clarity therefore calls the widely trumpeted quest for democratizing rural governance into question. The results of this study demonstrate that precisely carving out the role of traditional leaders within the framework of rural governance and development is a heavily politically sensitive issue. The government's relationship with traditional leaders is perhaps deliberately marked by ambiguity with the intention of preserving its discretion in the determination of the status of traditional leaders for strategic political goals.

The use of customary authorities as a strategic political bait was manifest in the Third Term Debate. In the lead up to the June 2004 general elections, there were attempts on the part of the government to amend the constitution in order to allow the President to serve more than two consecutive terms of office. Specifically targeting section 83 (3) of the constitution, the rationale for the proposed amendment was that "the provisions of section 83 (3) of the constitution are considered to infringe upon people's power to elect into office of President the person of their choice and renew his mandate for as many times as they may wish him or her to serve them" 24 . Meanwhile, the government had repealed (by Act $n^{\circ} 1$ of 2001) the Senate as a second chamber of Parliament in which the bulk of the Senators would have been chiefs, arguing on the government's questionable capacity to sustain two houses of Parliament. The abolition of the Senate was not a very welcome development among chiefs and as such they were clamouring for the formation of a Chiefs Council, widely projected as an alternative to the defunct Senate, whose roles

23. Interview with the Senior Programme Officer for the Malawi Germany Programme for Democratization and Decentralization (MGPDD).

24. The proposal to amend this constitutional provision was first meant to provide for a limitless term of office for the President. When it was defeated in Parliament on July 4 2002, the proposal was altered to seek for the amendment to allow the President to serve three consecutive terms over and above the two terms provided for in the constitution. 
would among others include: 1) providing inputs into the policy processes; 2) promoting tradition, culture and moral values; and 3) promoting interests and welfare of chiefs. The government was apparently very hesitant to bow down to the chiefs' demands for a council raising the following questions: Who was going to fund the Chiefs Council? What agenda would chiefs have to meet and discuss on a regular basis? Against this backdrop, the Department of Local Government (DLG) simply decided to create a chiefs' administrative unit within its establishment.

However, the Third Term Debate precipitated a dramatic turnaround in the fortunes of the Chiefs Council. At a public rally, President Muluzi unilaterally endorsed the formation of the Chiefs Council. He argued that the Chiefs Council would serve as a link between traditional leaders and the government through which chiefs could forward their needs and complaints, and act as an advisory body to the Office of the President and Cabinet (OPC) on activities of customary authorities ${ }^{25}$. Following the presidential endorsement at the public rally, an interim executive for the Chiefs Council was immediately constituted. The formation of the interim Chiefs Council executive was followed by several delegations of chiefs to Sanjika (the state palace) "proclaiming that they had been sent by their subjects to ask the President [Muluzi] to stand for the third term and request a referendum because chiefs felt betrayed since Parliament acted against the wishes of the people by rejecting the Open Term Bill'"26. The interviews with chiefs however revealed the extent to which the activities of the Chiefs Council were engineered from above for strategic political goals. Chief Chikulamayembe argued that the idea of Chiefs Council was good "but it was made to wear a different jacket altogether". According to Chief Zulu:

Chiefs never sat down to discuss the Third Term Debate, but during one of the many occasions chiefs were invited to Sanjika, those who were asked to speak just raised the issue and the rest of us just seconded it even though we never discussed it amongst ourselves. Some of us however genuinely supported it because we were convinced that there is nobody who can run this country better than President Muluzi.

When it however became increasingly imminent that the Third Term Bill had very little support, the fervent political support for the Chiefs Council effectively crumbled. According to the Department of Local Government officials, the chiefs' administration unit was instructed by higher authorities "to critically examine the legality of having a Chiefs Council"27. The legal advice sought from the Ministry of Justice characterized the existence of the Chiefs Council as "illegal because there is already a provision for the Chiefs Council in the Chiefs Act and as such there cannot be a separate body called Chiefs Council" ${ }^{28}$. It was thus pointed out that according to section 13 of the Chiefs Act "where the President has removed a person from the office of chief and is of the opinion that no other person is suitable for the position, he may appoint a Chiefs Council to perform the functions of that office". Had it been that the Third Term Bill had prevailed,

25. See Chiefs Used, Dumped, The Nation, 14th October 2003.

26. Ibid.

27. Interview with the Deputy Secretary for the Department of Local Government responsible for chiefs' administration unit.

28. Ibid. 
the feeling was that the Chiefs Council would not have been abandoned. It would have, in fact, become, in the view of most respondents opposed to the traditional leadership institutions, "a handmaiden for the destruction of the country's hard won democracy" 29.

\section{Concluding Reflections and Remarks}

The most intriguing finding of this study however is that in the eyes of the rural communities, customary authorities are considered far more legitimate catalysts for development and change compared to, for example, MPs and councilors. The reasons given in this regard included that customary authorities are the owners of the villages and that they live with them right in their villages, hence fully appreciate their problems. They are, unlike MPs and councilors, readily available when the people have problems, and for this particular reason, customary authorities were widely acknowledged as the main political administrative unit at the local level. They are in charge of such tasks as conflict resolution, crime prevention; they preside over various ceremonies, keep population registers, make decisions over community development projects and play a critical role in the moral restoration of society. They are thus largely regarded as custodians of local traditions and culture including land. It is the chiefs who make final decisions regarding access to, and use of land. Chiefs were thus extensively characterized as "the real leaders of local communities" ${ }^{\prime 30}$. In sharp contrast, councilors were consistently perceived as being less influential than traditional leaders since they cannot work on their own without working closely with traditional leaders "because we respond more to traditional leaders than anybody else"'31.

The fact that traditional leaders are considered far more legitimate from the vantage point of the grassroots mainly hinges on the fact that their livelihoods revolve around agriculture. The critical resource in this mode of livelihood happens to be land whose access and use are exclusively controlled by traditional leaders. Most people would not therefore afford to antagonize their relations with the chiefs because doing so would jeopardize the very core of their livelihoods. Moreover, through their control over land, traditional leaders often project themselves as a living symbol for a common heritage, identity and sense of belongingness for the people. This is often articulated in terms of the posterity of their positions compared to those of councilors and other similar elected positions of leadership whose incumbents come and go. The sense of permanence rooted in the common heritage, identity and belongingness therefore cultivates a milieu of pervasive trust among the grassroots in the traditional leaders, which is further buttressed by their centrality in their livelihoods in so far as access to the vital productive asset - land - is concerned.

Some accounts further attribute the pivotal role of traditional leaders in the livelihoods of the grassroots to their religious powers (Kaspin 1991, Moto 1998). This study did not however encounter evidence of such religious influence. While this might have been previously the case, there is at least evidence that such powers for traditional leaders have substantially waned. For instance, Probst (2002) provides some evidence of the decline

29. Interview with the Deputy Chief Planning Officer for the Department of Local Government.

30. Men Focus Group Discussion from Chapumbwa Village in Nkhata Bay DA.

31. Men Focus Group Discussion from Malengamzizi Village in Ntchisi DA. 
and erosion of the religious powers of traditional leaders especially in so far as rainmaking is concerned, observing that "The calling ritual that used to be carried out in February in times of drought or excessive rain, has given up... people no longer stick to the rules laid down by the ancestors" (Probst 2002: 182). In central Malawi, however, the remnants of the chiefly religious powers are still manifest especially through the village based nyau (spirits) mask societies. The nyau figures quite prominently during funeral and initiation ceremonies during which they perform. At the helm of the nyau performance during these ceremonies is the chief. The nyau masks are generally referred to as zirombo literally meaning wild animals that come from the bush into the village in order to accompany the difficult passages from youth to maturity and from life over to death to the realm of ancestors. Therefore where these practices are salient, the legitimacy of traditional leaders is further enhanced and entrenched. These ceremonies do not therefore only serve to produce a meaningful context for social action and identity but also makes the presence and influence of traditional leaders in the lives of their subjects more or less ubiquitous.

The pervasive conflict between customary authorities and councilors indicates that the articulation between decentralized powers and the powers already exercised in the local arena can affect the degree or the kind of decentralization. This underlies the fact decentralization does not take place in a vacuum (Boone 2000, Bierschenk and Olivier de Sardan 2002). This is an issue of even more critical concern when the process of institutionalizing decentralization policy reforms unnecessarily stalls as has been the case in Malawi. It has for example taken close to a decade to constitute DAs. There is thus little doubt that traditional leaders consequently exploited the virtual impasse in the reconstitution of DAs to reclaim, reassert and consolidate their strategic role in grassroots politics which, as already stated above, has always been a subject of contentious debate in the country's history of local governance and development. The point is that with such kind of impasse, various aspects of rural governance invariably became the default jurisdiction of customary authorities. What therefore might look like decentralization from the centre may actually turn out to be a centralizing force when it reallocates power that was by default exercised in the local arena to a different or even new set of institutions. This is very much what has happened with councilors assuming a decision making role regarding grassroots development projects which, for years, had been a role that customary authorities had taken more or less for granted to be theirs.

The apparent prominence of customary authorities among the grassroots as demonstrated in this study underlies, inter alia, the implicit close relationship between culture and politics. It is therefore compelling to argue that this relationship must be taken as a starting point in any efforts geared at domesticating the twin processes of democratization and decentralization, more especially given the unprecedented resilience traditional institutions have demonstrated amid attempts to either suppress or abolish them altogether. The challenge however for customary authorities to effectively play a midwife role in the efforts to domesticate and customize these processes to the exigencies of local conditions is their ill material circumstances, which render them easy targets for politicians bent on satisfying their own strategic political considerations, thereby entrenching the upward rather than the downward pattern of accountability which is the hallmark of democratization and decentralization. Understanding the implications of decentralization therefore requires a detailed understanding of the actors being created, supported and empowered in the resulting political landscape and their relationship to both the central state and the local population. 


\section{References}

Awoн, Kena, 2004. "Democratic Development: Gender Insights from the Grassroots in Nigeria", Canadian Journal of Development Studies, 25 (2), pp. 292-309.

BAKer, Collin, 1995. The Evolution of Local Government in Malawi. Ile-Ife: University of Ife Press.

Bierschenk, Thomas and Jean-Pierre Olivier de Sardan, 2002. "Powers in the Village: Rural Benin between Democratization and Decentralization", Working Paper, 4, Department of Anthropology and African Studies. Mainz: Guten-Berg-Universität.

Blom, Astrid, 2002. "Ambiguous Political Space: Chiefs, Land and the Poor in Rural Mozambique", in Neil Webster and Lars Eng-Perdersen (eds), In the Name of the Poor: Contesting Political Space for Poverty Reduction. New York and London: Zed Books.

Boone, Catherine, 2000. Decentralization as a Political Strategy in West Africa. Paper presented for the Colloquium Series on Decentralization and Development, April 20, 2000. Yale Centre for International and Area Studies.

Gould, Jeremy, 2001. Pluralism and Localization: Chiefs as Political Actors in Zambia's Third Republic. Paper presented at the Interrogating the New Political Culture in Southern Africa Conference, $13^{\text {th }}-15^{\text {th }}$ June 2001. Harare: Zimbabwe.

Hickey, Sam, 2003. "The Politics of Staying Poor in Uganda", CPRC Working Paper, 37. Institute for Development and Policy Management, University of Manchester .

Karlstrom, Mikael, 1996. "Imagining Democracy: Political Culture and Democratization in Buganda", Africa, 66 (4), pp. 17-34.

KASPIN, Deborah, 1991. Elephants and Ancestors: The Legacy of Kinship in Rural Malawi. PhD Dissertation: University of Chicago

Kaunda, Jonathan, 1992. "The Administrative Organization and Processes of National Development Planning in Malawi”, in Guy Mrone (ed.), Malawi at the Crossroads: The Postcolonial Economy. Harare: SAPES Books.

Lefebvre, Henri, 1991. The Production of Space. Oxford: Blackwell Publishing.

Lule, Godfrey, 1995. The Role of Traditional Leaders in the $21^{\text {st }}$ Century. Paper presented at Sheraton Hotel on $28^{\text {th }}$ July 1995. Kampala: Uganda.

Mamdani, Mawmood, 1996. Citizen and Subject: Contemporary Africa and the Legacy of late Colonialism. Kampala: Fountain Publishers.

Molotlegi, Leruo, 2002. Hereditary Rule in the Age of Democracy. Paper presented at Brown University, MacMillan Hall, $31^{\text {st }}$ October 2002. Also available at www.watsoninstitute.org

Мото, Francis, 1998. "Domesticating the Definition of Democracy", Bwalo: A Forum for Social Development, 2, pp. 24-43.

NTsebeza, Lungutsile

1999. "Land Tenure Reform in South Africa: An Example from the Eastern Cape Province", Dry Lands Issue Paper, 82. London: IIED.

2003. "Democracy in South Africa's Countryside: Is there a Role for Traditional Authorities?", Development Update, 4, pp. 54-80.

O’Laughlin, Bridget, 2000. "Class and the Customary: The Ambiguous Legacy of the Indigenato in Mozambique”, African Affairs, 99, pp. 5-42.

Obario, Juan, 2002. Legal Pluralism and Peace Process: The Ambiguous Reemergence of Customary Law in Mozambique. Peace and Global Security (Switzerland).

Owusu, Maxwell, 1997. "Domesticating Democracy: Culture, Civil Society and Constitutionalism in Africa", Society for Comparative Study of Society and History, 1, pp. 120-152. 


\section{Blessings Chinsinga}

Probst, Peter, 2002. "Expansion and Enclosure: Ritual Landscapes and the Politics of Space in Central Malawi", Journal of Southern African Studies, 28 (1), pp. 179-198.

Raftopoulous, Brian, 2002. “The State and Poverty Reduction Policies in Zimbabwe, 1980-1997”, in F. WiLson et al. (eds), Poverty Reduction: What Role for the State in Today's Globalized Economy? New York and London: Zed Books.

RAY, Donald, 1996. "Divided Sovereignty: Traditional Authority and the State in Ghana", Journal of Legal Pluralism and Unofficial Law, 37 \& 38, pp. 71-92 .

Riвот, Jessie, 2002. “African Decentralization: Local Actors, Powers and Accountability”, UNRISD Programme on Democracy, Governance and Human Rights. Paper Number 8. Stockholm.

SEnyonjo, Joseph, 2004. Traditional Institutions and Land. Available at www.federo.com/Pages/TraditionalIn stitutionsandland.htm

SorRI, Iina, 2002. Local Level: Always a Missing Link in Decentralization Process? The Politics of Decentralization in Mozambique (Unpublished).

Webster, Neil and Lars Engberg-Pedersen (eds), 2002. In the Name of the Poor: Contesting Political Space for Poverty Reduction. London and New York: Zed Books. 